УДК 502:33

DOI https://doi.org/10.32689/2522-4603.2021.1.6

\title{
Дмитро МИНЮК
}

кандидат юридичних наук, доцент, завідувач кафедри цивільно-правових дисциплін та міжнародного права Навчально-наукового інституту держави і права імені князя Володимира Великого, Міжрегіональна академія управління персоналом, вул. Фроментівська, 2, м. Київ, Україна, 03039,

\section{Ірина БАСОВА}

кандидат юридичних наук, доцент кафедри цивільно-правових дисциплін та міжнародного права Навчально-наукового інституту держави і права імені князя Володимира Великого,

Міжрегіональна академія управління персоналом, вул. Фроментівська, 2, м. Київ, Україна, 03039, basova.civil@gmail.com

\section{Dmytro MYNIUK}

Candidate of Law, Head of the Department of Civil Law and International Law of the Educational and Scientific Institute of Law named after Prince Vladimir the Great, Interregional Academy of Personnel Management, 2 Frometivska str., Kyiv, Ukraine, 03039

\section{Iryna BASOVA}

Candidate of Law, Associate Professor at the Department of Civil Law and International Law of the Educational and Scientific Institute of Law named after Prince Vladimir the Great, Interregional Academy of Personnel Management, 2 Frometivska str., Kyiv, Ukraine, 03039, basova.civil@gmail.com

\section{МІЖНАРОДНЕ СПІВРОБІТНИЦТВО У СФЕРІ ОХОРОНИ НАВКОЛИШНЬОГО ПРИРОДНЬОГО СЕРЕДОВИЩА}

\section{INTERNATIONAL COOPERATION IN THE FIELD OF ENVIRONMENTAL PROTECTION}

Стаття присвячена дослідженню міжнародно-правової бази у сфері охорони навколишнього природнього середовища та віднаходженню шляхів з удосконалення національного законодавства у иій сфері.

Метою даної статті є дослідження міжнародного співробітництва у сфері охорони навколишнього природнього середовища крізь призму міжнародної правотворчої діяльності, а також внесення пропозицій щодо ї̈ удосконалення.

Визначення міжнародних органів та установ, до повноважень яких входить забезпечення охорони навколишнього природнього середовища. Опращювання основних міжнародно-правових актів у иій сфері загалом та міжнародних договорів, стороною яких є Украӥна.

3'ясування основних принципів, на яких має будуватися національна нормативно-правова база та екологічна політика держави.

Методологічну основу даної статті склали, насамперед, порівняльно-правовий метод та методи аналізу та синтезу.

Наукова новизна. Чинне законодавство Украйни з охорони навколишнього природнього середовища потребує удосконалення, зокрема у частині приведення його окремих положень до міжнародних стандартів. Удосконалити систему управління відходами України згідно з положеннями проєкту Європейського Союзу «Управління і регулювання відходами - Інструмент Європейського добросусідства і партнерства - Схід», стороною якого є Україна.

Як висновок, аналіз міжнародно-правової бази з питань з охорони навколишнього природнього середовища свідчить, що українське законодавство загалом побудоване на нормах міжнародно-правових актів. Водночас варто визнати, щяо існуе коло проблемних питань, щңо підлягають удосконаленню.

Ключові слова: міжнародно-правова база у сфері охорони навколишнього природнього середовища, право на безпечне для життя $і$ здоров'я довкілля, збереження природних систем, міжнародне співробітництво у сфері охорони навколишнього природнього середовища.

The article is devoted to the study of the international legal framework in the field of environmental protection and finding ways to improve national legislation.

The purpose of this article is to study international cooperation in the field of environmental protection through the prism of international lawmaking, as well as to make suggestions for its improvement.

Identification of international bodies and institutions whose powers include ensuring environmental protection. Elaboration of the main international legal acts in this field in general and international agreements to which Ukraine is a party. 
Clarification of the basic principles on which the national legal framework and environmental policy of the state should be built.

The methodological basis of this article was, first of all, the comparative law method and methods of analysis and synthesis.

Scientific novelty. The current legislation of Ukraine on environmental protection needs to be improved, in particular in terms of bringing its individual provisions to international standards. Improve the waste management system in accordance with the provisions of the European Union project "Waste Management and Regulation European Neighborhood and Partnership Instrument - East", to which Ukraine is a party.

In conclusion, the analysis of the international legal framework on environmental protection shows that its provisions are enshrined in Ukrainian legislation in general based on the rules of international law. At the same time, it should be recognized that there are a number of problematic issues that need to be improved.

Key words: international legal framework in the field of environmental protection, the right to a safe environment for life and health, preservation of natural systems, international cooperation in the field of environmental protection.

Забезпечення охорони навколишнього природного середовища є однією 3 ключових засад розвитку і ефективного функціонування як держави загалом, так і екологічної, економічної, соціальної сфери зокрема. Таке забезпечення знаходить своє пряме втілення в положеннях Конституції України та відповідних нормативно-правових актах. Так, Основний Закон України визначає коло прав у сфері охорони навколишнього природнього середовища, зокрема «право на безпечне для життя і здоров'я довкілля, на відшкодування завданої порушенням цього права шкоди, вільного доступу до інформації про стан довкілля, про якість харчових продуктів і предметів побуту, а також право на її поширення» [1].

Слід погодитися, що світ в цілому і Україна у тому числі, тривалий час зазнавали і зазнають до сьогодні значну кількість природніх лих, техногенних катастроф. Неможна виключати, що витоком глобальних екологічних проблем є людський фактор. Масштабність цієї проблеми зумовлює необхідність її вирішення не окремо взятою державою, а міжнародною спільнотою, шляхом міжнародного природоохоронного співробітництва.

Головними чинниками, що впливають на активне міжнародне природоохоронне співробітництво $\epsilon$ «глобальний характер багатьох екологічних проблем; транскордонний характер забруднення; наявність міжнародних природних ресурсів; вигоди від міжнародного обміну досвідом та технологіями, можливості залучення міжнародних інвестицій» [2, с. 71].

Погоджуючись 3 думкою науковців у сфері охорони навколишнього природнього середовища та раціонального природокористування основними напрямками розвитку міжнародного співробітництва $є$ : «(а) збереження природних систем, які не використовуються в господарській діяльності і сприяють підтримці екологічної рівноваги; (б) раціональне використання природних ресурсів; (в) створення ефективної системи міжнародної екологічної відповідальності, у тому числі відповідальності за руйнування навколишнього середовища внаслідок воєнних дій» [2, с. 71]. Досягти позитивного результату у цій галузі можливо шляхом спільних взаємних дій та заходів держав. В цьому контексті слід говорити про фінансовий і технічний бік, «впровадження ресурсозберігаючих і енергозберігаючих технологій; структурної перебудови національних економік у напрямку екологізації господарського комплексу; створення механізму міжнародної відповідальності у галузі охорони навколишнього природного середовища; вдосконалення екологічного оподаткування» [3, с. 14] та ін.

Однією із основних форм міжнародної співпраці щодо вирішення проблем навколишнього середовища $є$ міжнародні договори. Їх укладення обумовлюється наявністю спільних екологічних проблем та необхідність ефективного вирішення та врегулювання.

Міжнародне співробітництво у сфері охорони навколишнього природнього середовища має давню історію. Не зайвим буде зазначити, що одним 3 перших міжнародних нормативно-правових актів у цій сфері $\epsilon$ Декларація про птахів, 1875 року, укладена між Австро-Угорщиною та Італією

На сьогодні, міжнародна нормативно-правова база в галузі охорони навколишнього середовища та раціонального природокористування на сьогодні є досить широкою. Такими зокрема $\epsilon$ Резолюція ООН «Економічний розвиток і охорона природи», 1962 року, змістом якої охоплюється програма щодо охорони навколишнього природнього середовища; Декларація ООН з проблем оточуючого людину середовища, 1972 року [4] (Стокгольм, Швеція); Конвенція ООН «Хартія морів», 1982 року з морського права, що закріплює основні критерії охорони морського середовища під час використання ресурсів морського дна, наприклад закріплений обов'язок «оберігати морське середовище та захищати його від забруднення» [5]; Декларація Ріо про навколишнє середовище і розвиток, 1992 року [6] (Ріо-де-Жанейро, Бразилія) та інші. Для прикладу, Положення Декларації Pio про 
навколишнє середовище і розвиток містить 27 принципів, зокрема: «право на здорове і плідне життя у гармонії 3 природою; суверенне право держави розробляти свої власні ресурси, не завдаючи шкоди навколишньому природному середовищу за межами їхніх кордонів; принцип співпраці держави щодо збереження, захисту та відновлення цілісності екосистем Землі; принцип вжиття державою заходів з питань охорони довкілля шляхом розроблення відповідних національних законів; принцип відповідальності, у тому числі фінансової, за забруднення навколишнього природнього середовища» [6].

Окрім міжнародного нормативно-правового регулювання формою міжнародного співробітництва $\epsilon$ створення i діяльність спеціалізованих організацій при Організації Об'єднаних Націй. Йдеться зокрема про екологічні органи, центри, комісії, групи тощо. Серед основних можна назвати Всесвітню метереологічну організацію (ВМО), Організацію об'єднаних націй з питань освіти, науки і культури (ЮНЕСКО), Всесвітню організацію охорони здоров'я (ВООЗ), Свропейську економічну комісію (СЕК), Міжнародну морську організацію (ММO), Міжнародну організацію з радіологічного захисту (МАГАТЕ), Міжнародну спілку охорони природи та природних ресурсів (МСОП), Міжнародну комісію з охорони довкілля і розвитку (МКОДР), Глобальний фонд навколишнього середовища (ЕФОС). Провідні експерти ООН вважають, що «для вирішення глобальних екологічних проблем сучасності, необхідно спрямувати міжнародні зусилля на: дослідження та аналіз основних причин кризи та боротьбу з iї наслідками, залучення широкої громадськості, забезпечення засобів правового регулювання та інвестування в майбутнє» [62].

Міжнародне співробітництво України у сфері охорони навколишнього природнього середовища визначається основними напрямами державної екологічної політики, шляхом розроблення екологічних програм, прийняття нормативно-правових актів та укладення міжнародних договорів. Тісна співпраця України з іноземними державами у цій сфері та їх позитивний законодавчий і практичний досвід $\epsilon$ рушійною силою для ефективного вирішення нагальних проблем в нашій державі.

Слід зазначити, що Україна в особі Міністерства екології та природних ресурсів ратифікувала більше 50 конвенцій та угод 3 питань охорони навколишнього природного середовища та раціонального природокористування. Серед системи таких актів можна виокремити Конвенцію ООН «Про охорону дикої флори і фауни та природних середовищ існування в Європі» (Бернська угода); Конвенцію ООН «Про транскордонний вплив промислових аварій»; Базельську конвенцію «Про контроль за транскордонним перевезенням небезпечних відходів та їх видаленням»; Стокгольмську конвенцію «Про стійкі органічні забруднювачі»; Роттердамську конвенцію «Про процедуру попередньої обгрунтованої згоди відносно окремих небезпечних хімічних речовин та пестицидів у міжнародній торгівлі»; Свропейську ландшафтну конвенцію [2] тощо. Україна як член OOH підписала і ратифікувала міжнародні договори в екологічній сфері, зокрема з таким країнами, як Грузія, Молдова, Словаччина, Польща, а також Австрією, Фінляндією, Ізраїлем, Данією, Нідерландами, США. Показовим в галузі ядерної та радіаційної безпеки в межах програми TACIS Україна співпрацює iз МАГАТЕ і Європейським Союзом, а також на двосторонній основі з США, ФРН, Канадою, Швецією та Японією [8].

Більш того, Україна з 1995 року є членом Ради Свропи у сфері охорони навколишнього середовища. Пріоритетними напрямками діяльності асоціації Україна - Свропейський Союз $є$ «дотримання Україною стратегії та принципів розвитку 3 питань навколишнього природного середовища на період до 2025 року з метою забезпечення можливості вживати заходів для здійснення бюджетної підтримки; удосконалення норм чинного законодавства України, зокрема щодо оцінки впливу, стратегії, доступу до інформації у сфері навколишнього природного середовища та участі громадськості; розвиток національних правових інструментів відповідно до багатосторонніх угод у сфері навколишнього природного середовища підписаних та ратифікованих Україною та Свропейським Співтовариством (Стокгольмська Конвенція, Конвенція про захист річки Дунай, Рамкова Конвенція про зміну клімату, Кіотський Протокол, Монреальський Протокол, Конвенція про охорону європейського природного середовища (Рада Європи) тощо); впровадження Кіотського протоколу через діалог в рамках спільної робочої групи Україна - СС 3 питань зміни клімату; забезпечення реалізації Бухарестської конвенції і протоколів до неї та спільній роботі з Сторонами Конвенції для забезпечення приєднання Європейського Співтовариства до Конвенції» [9].

Про тісну співпрацю України з Європейським Союзом свідчить створення у 2008 році Регіонального екологічного центру в Україні, метою якої є: (а) «надання допомоги у вирі- 
шенні екологічних проблем в Україні та сусідніх державах, забезпечуючи екологічні права людини та створюючи умови для існування безпечного довкілля; (б) розвиток вільного обміну інформацією щодо навколишнього природного середовища та розповсюдження такої інформації між усіма зацікавленими сторонами; (в) сприяння участі громадськості в процесі прийняття рішень щодо захисту навколишнього природного середовища, a отже і розвиток громадянського суспільства в Україні та інших країнах» [2, с. 72].

Окремої на уваги заслуговує проєкт Європейського Союзу «Управління і регулювання відходами - Інструмент Європейського добросусідства і партнерства - Схід», стороною якого $є$ Україна [2, с. 72]. Основними його засадами $\epsilon$ «зниження ризиків, пов'язаних 3 нераціональним використанням відходів у цих країнах» [2, с. 72]. Цей проєкт спрямований на «вдосконалення систем управління відходами, запровадження більш ефективних ініціатив щодо запобігання утворення відходів, підвищення потенціалу для збору і сортування, а також збільшення повторного використання, відновлення та безпечного видалення відходів» [2, с. 72]. Він може стати орієнтиром для країн-учасниць при форму- ванні національної політики, а також створенні дієвих механізмів управління відходами.

Вказане дозволяє 3 впевненістю стверджувати, що Україна $\epsilon$ активним учасником міжнародних еколого-правових правовідносин. Незважаючи на досить активну позицію України на міжнародній арені щодо сприяння покращенню навколишнього природнього середовища та вирішення пов'язаних 3 цим проблем, слід констатувати, що на сьогодні в нашій державі спостерігається глибока екологічно-економічна криза. Погоджуємося 3 думкою науковців в галузі охорони навколишнього природнього середовища, що ця криза $є$ наслідком виробничої діяльності людини, високої концентрації промислового виробництва, нераціонального використання природних ресурсів, відсутності дієвої законодавчої бази.

Таким чином, для зміни стану навколишнього природнього середовища в Україні першочергового варто привести чинне національне законодавство у цій сфері до міжнародних стандартів. Дотримання визначених міжнародно-правовими актами принципів збереження та охорони навколишнього природнього середовища $є$ запорукою розвитку та процвітання держави.

\section{Література:}

1. Конституція України: Закон України від 28.06.1996 р. № 254к/96-BP. URL: https://zakon.rada.gov.ua/ laws/show $/ 254 \% \mathrm{D} 0 \% \mathrm{BA} / 96 \% \mathrm{D} 0 \% \mathrm{~B} 2 \% \mathrm{D} 1 \% 80 \#$ Text

2. Гладка Л.І., Шаляпіна А.С. Світовий досвід та співробітництво України у сфері охорони навколишнього природного середовища. Проблемы материальной культуры. Экономические науки. 2020. C. $70-73$.

3. Богачов, В. Необхідність підвищення екологічної безпеки в Україні: наукова стаття. Економіст. 2018. № 9. C. $12-14$.

4. Декларація ООН з проблем оточуючого людину середовища: Декларація ООН від 16.06.1972 p. URL: https://zakon.rada.gov.ua/laws/show/995_454\#Text.

5. Джигирей, В. С. Основи екології та охорони навколишнього природного середовища. Екологія та охорона природи: навчальний посібник. 2-ге вид., доп. Львів : Афіша, 2014. 272 с.

6. Декларація Ріо про навколишнє середовище і розвиток: Декралація від 14.06.1992 p. URL: https://www.ecoleague.net/forumy-konferentsii-kruhli-stoly-seminary/ekolohichnyi-kalendar/cherven/item/ 354-pryiniattia-deklaratsii-rio-de-

7. Батлук В. А. Основы экологии и охрана окружающей среды: учебное пособие. Львов : Афиша, 2011. $264 \mathrm{c}$.

8. Шевцов А. I., Земляний М. Г., Дорошкевич А. З. Ядерна безпека в Україні. URL: http://www.db.niss.gov.ua/docs/energy/143.htm.

9. Арбатова Н. К. Співробітництво України та ЄC в сфері охорони довкілля. URL: http://lib.znate.ru/ docs/index-272010.html?page $=3$.

\section{References:}

1. Constitution of Ukraine: Law of Ukraine of June 28, 1996 № 254k / 96-VR. URL: https://zakon.rada. gov.ua/laws/show $/ 254 \% \mathrm{D} 0 \% \mathrm{BA} / 96 \% \mathrm{D} 0 \% \mathrm{~B} 2 \% \mathrm{D} 1 \% 80$ \# Text.

2. Gladka, L.I., Chaliapina A.S. (2020) World experience and cooperation of Ukraine in the field of environmental protection. Problems of material culture. Economic Sciences, pp. 70-73.

3. Bogachev, V. (2018) The need to improve environmental safety in Ukraine: a scientific article. Economist, no. 9 , pp. $12-14$.

4. UN Declaration on the Problems of the Human Environment: UN Declaration of 16 June 1972. URL: https://zakon.rada.gov.ua/laws/show/995_454\#Text. 
5. Dzhigirey, V.S. (2014) Fundamentals of ecology and environmental protection. Ecology and nature protection: a textbook. 2nd ed., Ext. Lviv: Afisha [in Ukrainian].

6. Rio Declaration on Environment and Development: Declaration of 14 June 1992. URL: https://www.ecoleague.net/forumy-konferentsii-kruhli-stoly-seminary/ekolohichnyi-kalendar/cherven/ item/354-pryiniattia -declarations-rio-de-

7. Batluk, V.A. (2011) Fundamentals of ecology and environmental protection: a textbook. Lviv: Afisha [in Ukrainian].

8. ShevtsovAI,Zemlyany MG, DoroshkevichAZ Nuclear safety in Ukraine. URL:http://www.db.niss.gov.ua/ docs/energy/143.htm

9. Arbatova NK Cooperation between Ukraine and the EU in the field of environmental protection. URL: http://lib.znate.ru/docs/index-272010.html?page=3. 